\title{
DAMAGED DROP HYDRAULIC STRUCTURE AS AN EXAMPLE OF NATURAL RENATURALIZATION PROCESS OF RIVER: THE DOBRZYCA RIVER, NORTH WEST POLAND
}

\author{
Karol Plesiński ${ }^{1 \bowtie}$, Artur Radecki-Pawlik², Michał Bień ${ }^{3}$, Kamil Suder $^{1}$ \\ 1 Department of Hydraulic Engineering and Geotechnics, Faculty of Environmental Engineering and Land Surveying, University of \\ Agriculture in Krakow, Al. Mickiewicza 24/28, 30-059 Kraków \\ 2 Division of Structural Mechanics and Material Mechanics, Faculty of Civil Engineering, Cracow University of Technology, \\ Warszawska 24, 31-155 Kraków, Poland \\ 3 ZANDER, Aquaculture \& Hydroponics, Fish Farm
}

\begin{abstract}
\section{Aim of the study}

The paper presents an assessment of capacity of a drop hydraulic structure, which was partially destroyed, and provides a description of slow renaturalization of a riverbed in this area. As a result of damage to the hydrotechnical structure caused by natural processes, some elements detached from the structure were deposited in an energy dissipation basin and in the riverbed downstream of the structure, impeding rock and vegetal debris traffic. These fluvial processes formed a cascade-like structure that led to a change in the regime of water flow through the hydrotechnical structure that was not planned or designed originally.
\end{abstract}

\begin{abstract}
Material and methods
Due to partial destruction of the structure, the water flow regime was so drastically altered that it is possible for various species of fish to cross this section of river without any additional constructions like fish passes. Field measurements determined six potential fish migration routes through the damaged structure's area. Then each fish migration route was evaluated against the possibility for fish to pass through the structure.
\end{abstract}

\section{Results and conclusions}

The analysis showed that the partly damaged drop hydraulic structure creates favourable conditions for migration of some fish species. It can be concluded that the elements detached from the drop hydraulic structure and deposited downstream should not be removed from the riverbed, because they improve the environmental conditions for aquatic organisms in terms of their migration.

Keywords: drop hydraulic structure, river restoration, fish migration, the Dobrzyca River

\section{INTRODUCTION}

Many anthropogenic hydrotechnical structures around the world impede fish migration (Bylak et al., 2009; Wiśniewolski et al., 2004; Kukuła et al., 2008). These barriers affect significantly river and stream ichthyofauna (Bylak, 2018; Jędryka, 2009). Apart from the impact on environmental conditions, these objects also modify the natural geomorphological system of a riverbed and the water flow regime (Plesiński, 2018a; Bylak et al., 2017). It can be said that the impact of low-level hydrotechnical constructions on the conditions in riverbeds is similar to that of large dams, although their influence is smaller, local and less in-

凶e-mail:kplesinski@ar.krakow.pl 
tense (Allan and Lkecker, 1993; Bylak and Kukuła, 2018; Kukuła and Bylak, 2011). The larger the number of this type of structures on a watercourse, the more influential it becomes. (Bylak et al., 2017).

Natural river ecosystems form an uninterrupted stream that flows from the source to the mouth. This is called continuity or capacity of a watercourse. Until recently, this term was understood as "watercourse bed condition, which allows free and unimpeded flow of water, ice or any material carried through a river" (Jędryka, 2009). By definition, it was more about ensuring geomorphological (river debris transport) as well as hydrological and hydraulic (water transport) conditions. So far, the ichthyofauna inhabiting the watercourse was omitted. Fish are not "material carried by a river" and their swimming abilities that enable migrations are distinguished by species and even individual predispositions. It is misleading to think of fish as being transported by river, because fish can choose their routes depending on needs, either in search of food or for breeding, travelling upor downstream to sites suitable for spawning (from rivers to lakes, from sea to rivers, or up and down the same rivers to suitable tributaries, or sites with right parameters for spawning). Currently, a new definition of "ecological continuity of a watercourse" has been adopted, including also fish migration that is not impeded by any hydrotechnical constructions (Jędryka, 2009; Vannote et al., 1980; Seliger and Zeiringer, 2018).

This approach demonstrates greater public ecological awareness than just a few years ago. Poland's membership in the European Community gave a new perspective on ecological issues in river valleys and riverbeds (Dyrektywa, 2000). Not only technical and engineering conditions are observed now, but ecological, too. It is important that the hydrotechnical construction, in addition to its typical functions, such as flood protection, water damming for various economic or tourist purposes, fulfils also ecological purposes, mainly ensuring continuity for fish migrating in a riverbed (Lubieniecki, 2002). Renaturalization of rivers becomes important, sometimes leading to abandoning hydrotechnical construtions, their removal or spontaneous deterioration due to fluvial processes (Kałuża and Hammerling, 2015; Radecki-Pawlik et al., 2015; Żelazo and Popek, 2014).
The rise of awareness of the importance of watercourse ecological continuity among water management decision-makers and hydrotechnical engineers is demonstrated by their cooperation with environmental institutions, biologists, ichthyologists and even anglers (Prus et al., 2018). In effect of such cooperation, numerous projects were realised that aimed at revitalizing and renaturalizing river valleys and riverbeds, as well as reconstructions of hydrotechnical structures that do not meet ecological requirements (Kałuża et al., 2016; Kałuża et al., 2018; Szałkiewicz et al., 2019; Lubieniecki, 2002). By the notions of revitalization and renaturization we mean a number of processes occurring in riverbeds and/or in river valleys that improve fluvial and/or riverine environment, preferably to a condition as close as possible to natural state before degradation (Bojarski et al., 2005; Żelazo and Popek, 2014). In the West Pomeranian Voivodeship, in the recent past, two projects have been implemented to clear the entire catchment. First program was titled 'Construction of blue ecological corridor along the Rega river valley and its tributaries' (Witkowska et al., 2013a; 2013b), the other - 'Construction of blue ecological corridor along the Ina river valley and its tributaries' (Durkowski, 2017). The projects were run between 2012 and 2017 in catchment areas of Rega and Ina rivers by the West Pomeranian Board of Amelioration and Water Facilities in Szczecin with the participation of the Regional Directorate for Environmental Protection in Szczecin. In both projects, improving environmental conditions for migrating fish included:

- construction of 23 (the Rega catchment) and 28 (the Ina catchment) hydrotechnical devices for fish migration. They were mainly technical fish passes, circulation channels - so-called bypasses and riffles with increased roughness. Existing and inoperative fish passes were modernized (both in the Ina catchment). Devices that monitor and record fish flow have been installed on many new facilities, so it is possible to assess fish migration efficiency and to eliminate immediately all dangers arising during these migrations. The issue with lack of luring current at some fish passes was solved by installing electric-electronic barriers (4 objects in the Rega catchment).

- construction of $12,000 \mathrm{~m}^{2}$ and $300 \mathrm{~m}^{2}$ spawning grounds in the Rega and Ina catchments. 
- forestation of river banks (47 km and $23 \mathrm{~km}$ in the Rega and Ina catchments, respectively), in order to improve the environment by providing shade and lowering the water temperature.

Presented research focused on analysing the impact of the dimensions and hydrodynamic parameters of the damaged drop hydraulic structure on fish migration. Fluvial processes and floods lead to gradual deterioration of this drop hydraulic structure, which became an example of spontaneous renaturization of riverbed after all hydrotechnical interference such as renovating or reconstructing the facility was ceased.

\section{DESCRIPTION OF THE STUDIED OBJECT}

The research took place at the drop hydraulic structure located $25 \mathrm{~km}$ from the source of the Dobrzyca River - a $66 \mathrm{~km}$ long sixth-order stream. The source of the river is located near Czaplinek and the Łupowo village, from where it flows south-east. In Machliny the river passes through Lake Machliny Wielkie. Its first tributary is Świeczyniec, which joins the river just before the village of Dobrzyca. Further on, the river continues south-east, until it reaches the Kłębowianka tributary, where the watercourse shifts more

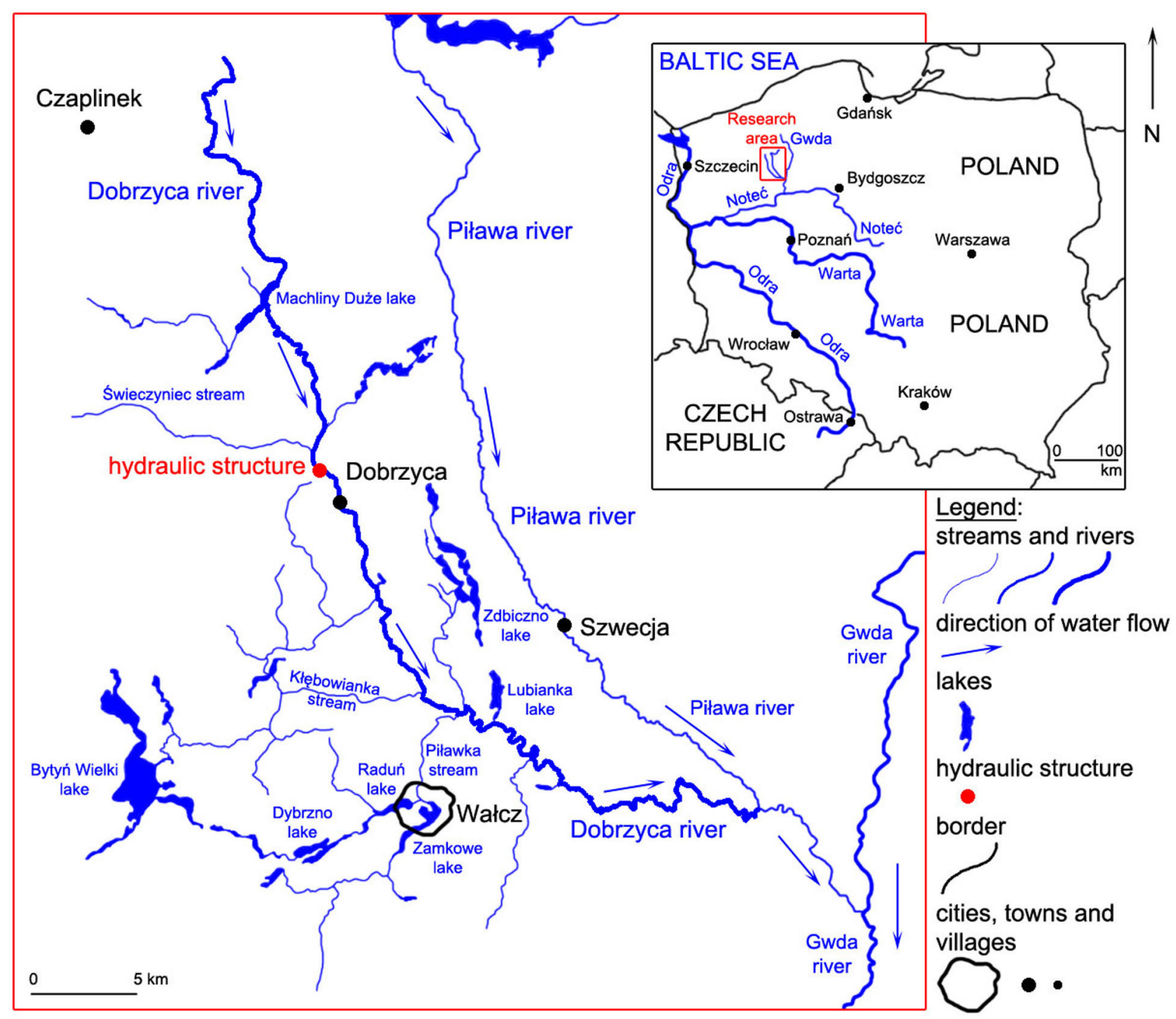

Fig. 1. The map of the Dobrzyca River catchment with marked research object 
to the east. Because of the change of direction, the river goes about $2 \mathrm{~km}$ to the north-east of Wałcz, without flowing into the town. Its direction changes only around the village of Czapla, where the river turns east. After travelling a few kilometers, it enters Piława, which in turn is a right-bank tributary of the Gwda. And Gwda flows into the Noteć River, Noteć into the Warta River, and in the end - Warta into the Oder River. The $925 \mathrm{~km}^{2}$ large catchment area is located in the Wałeckie Lakeland (right part of the catchment) and on the Wałęcka Plain (left part of the catchment together with the Dobrzyca River) (Kondracki 2000).

The object of research is the drop hydraulic structure, which was destroyed by nature forces. It has the following dimensions:

- width: $18.5 \mathrm{~m}$,

- original height: $1.5 \mathrm{~m}$,

- $\quad$ spillway crown length: $1.5 \mathrm{~m}$.

Below the drop hydraulic structure lied probably an energy dissipation basin, but it was not noticed during the field visit. The reason for this may be its chocking with stones or ruining. The energy dissipation basin threshold, which is often formed as the drainage's end, was also not found.

\section{METHODOLOGY}

The field measurements included:

- geodetic measurements of structure, bed and water table,
- measurements of hydrodynamic parameters of water flow.

Geodetic measurements were taken with a Topcon GTS-226 total station. It allows for measuring the facility and creating longitudinal profiles, which potentially could be migration routes for fish. Measurements of water table were to determine the gradient between adjacent structures.

Hydrodynamic measurements were carried out mainly in places that could be a barrier for migrating fish (spillways, indentations in structure, sites of increased flow concentration and velocity) and in sites of calmer water, where fish can hide and rest (swimming pools, chambers and overdeepenings). Mainly, those parameters were measured that may affect fish migration. These included filling $\mathrm{h}$ and water flow velocity $V$, which enabled determining vertical velocity profiles. Hydrodynamic measurements were made using a Valeport EM Flow-Meter 801 Flat current meter.

Both geodetic and hydrodynamic measurements were taken in six longitudinal profiles, which potentially can be routes for fish migration. Measurements were made at low flow $Q=1.3 \mathrm{~m}^{3} \cdot \mathrm{s}^{-1}$.

Research consisted in assessing the capacity of the analysed structure for fish species inhabiting the riverbed (Penczak et al., 1986) based on values of hydrodynamic parameters measured during field visit (see: Table 1).

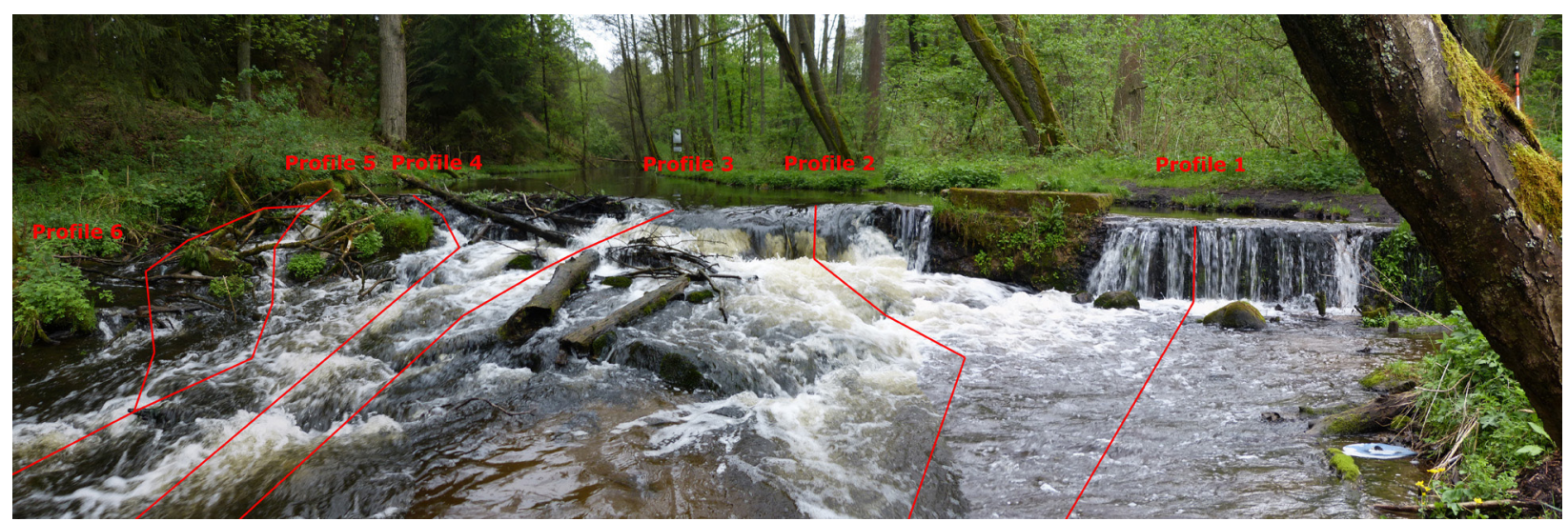

Fig. 2. Hydraulic structures with marked profiles (photo by K. Plesiński) 
Table 1. Values of acceptable geometrical and hydrodynamic parameters in regard to enabling fish migration through a hydrotechnical object (based on: DWA, 2014; DVWK, 2002; Gebler, 1991; Bartnik i in., 2011; Sakowicz i Żarnecki, 1954; Schmutz i Mielach, 2013)

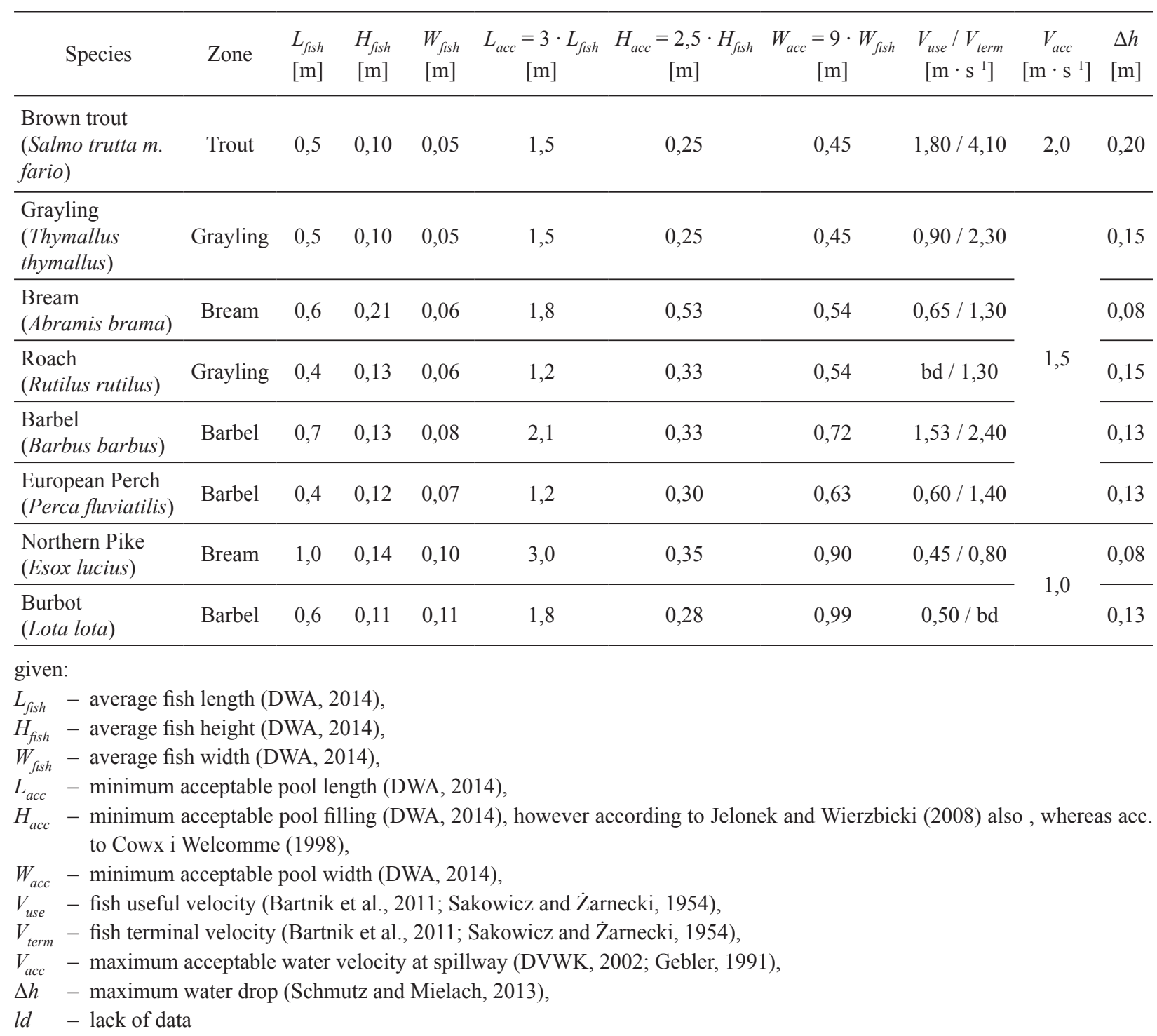

\section{RESEARCH RESULTS AND DISCUSSION}

Profile no. 1 was designed, where the drop hydraulic structure's shape was the closest to its original condition. Ruptured concrete slab, which was a crown of a spillway, was the most major change in this part of the structure - due to thus the spillway dropped by $0.22 \mathrm{~m}$. Hydrodynamic measurements show that the maximum flow velocities were low, reaching only $V_{\text {max }}=0.24 \mathrm{~m} \cdot \mathrm{s}^{-1}$ and $0.25 \mathrm{~m} \cdot \mathrm{s}^{-1}$ above and below the structure respectively. In turn, at the drop hydraulic structure's spillway, velocity was $V_{\max }=0.52 \mathrm{~m} \cdot \mathrm{s}^{-1}$. Large water drop, which was $\Delta h=0.9 \mathrm{~m}$, proves capacity failure at this profile. Under such conditions, no fish species found in the river were able to make such a high and long jump. 


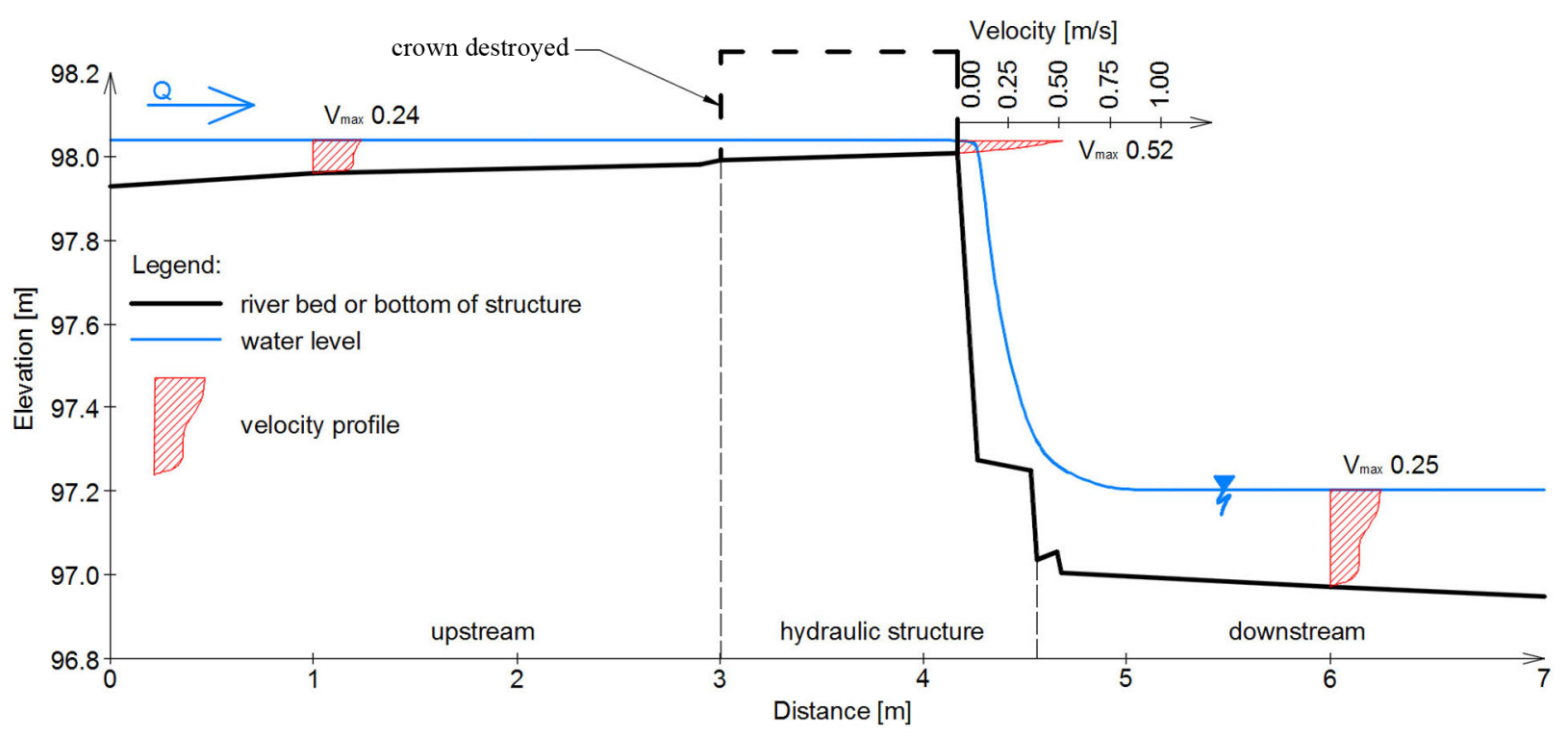

Fig. 3. Profile no. 1

Profile no. 2 was drafted to the right of Profile no. 1, which was more damaged. Below the spillway were deposited concrete elements (marked in the diagram as spillways no. 2 and 3), which were detached from the drop hydraulic structure. These elements dammed up the water, creating deep pools above the facility. Depth of the first was $H=0.7 \mathrm{~m}$ and of the second $-H=0.33 \mathrm{~m}$. The maximum water velocity was $V_{\max }=1.47 \mathrm{~m} \cdot \mathrm{s}^{-1}$ and $V_{\max }=1.33 \mathrm{~m} \cdot \mathrm{s}^{-1}$ in the first and second pool, respectively, however, these values occurred at water table. In the lower parts of the pools, velocity was significantly lower, usually not exceeding $V=0.50 \mathrm{~m} \cdot \mathrm{s}^{-1}$ and $V=0.75 \mathrm{~m} \cdot \mathrm{s}^{-1}$. Despite favourable conditions in the pools for all of the considered fish species (except for bream, for which filling of the pool 2 was too low with $H_{a c c}=0.53 \mathrm{~m}$ ), the problem could be the spillways generating excessive velocity. At the two lowest spillways, maximum velocity was $V_{\text {max }}=1.57 \mathrm{~m} \cdot \mathrm{s}^{-1}$ and $V_{\text {max }}=1.67 \mathrm{~m} \cdot \mathrm{s}^{-1}$, which enabled only trout to reach the pool no. 1 . Unfortunately, despite the fact that trout could enter the pool no. 1, the main spillway (no. 1) posed an insurmountable obstacle, because the water drop was too high, $\Delta h=0.3 \mathrm{~m}$. Also, velocity of overflowing water there was very high, from $V_{\min }=1.12 \mathrm{~m} \cdot \mathrm{s}^{-1}$ at the ground to $V_{\max }=1.97 \mathrm{~m} \cdot \mathrm{s}^{-1}$ at water table.
Profile no. 3 was located in the central part of the structure. Wood rubble, besides concrete elements, was found in the riverbed below the structure. Excessive height of spillway crown, amounting to $0.35 \mathrm{~m}$, demonstrated how choked the drop hydraulic structure was. This meant that no species of fish inhabiting the riverbed could pass through, despite significant filling of basin no. $1(H=0.42 \mathrm{~m})$. Brown trout and grayling were able to reach only up to this point. In turn, despite low velocity values $\left(V<1.0 \mathrm{~m} \cdot \mathrm{s}^{-1}\right)$ on the spillway no. 3 and in the pool no 2, other species of fish could not enter into the pool no. 2, because its filling $(H=0.26 \mathrm{~m})$ and length $(L=1.6 \mathrm{~m})$ were below acceptable values.

Profile no. 4 was characterized by a single $H=$ $0.7 \mathrm{~m}$ deep and $L=1.75 \mathrm{~m}$ long pool. Such a large depth created favourable spatial conditions for fish to accelerate and make a jump long and high enough to cross the obstacle. The water drop at the spillway no. 2 (below the pool) was $\Delta h=0.19 \mathrm{~m}$, and flow velocity $V_{\max }=1.64 \mathrm{~m} \cdot \mathrm{s}^{-1}$. The velocity profile has shown little variety. These parameters indicate that only brown trout could enter the pool no. 1. Above the pool no. 1 was the main spillway (no. 1) with convenient shapes (Dąbkowski et al., 1982), i.e. the stream did not escape from the structure's bed, but only slid on its surface. 


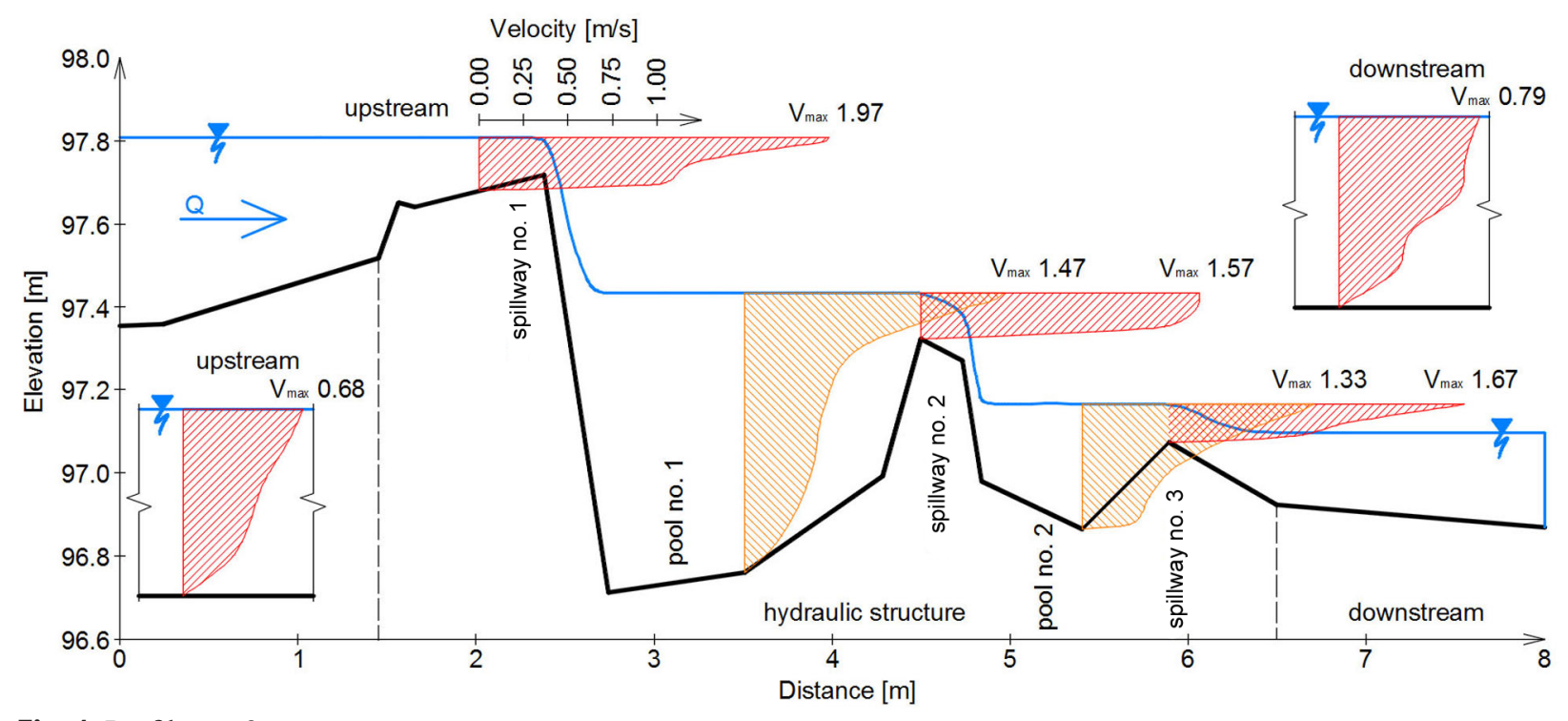

Fig. 4. Profile no. 2

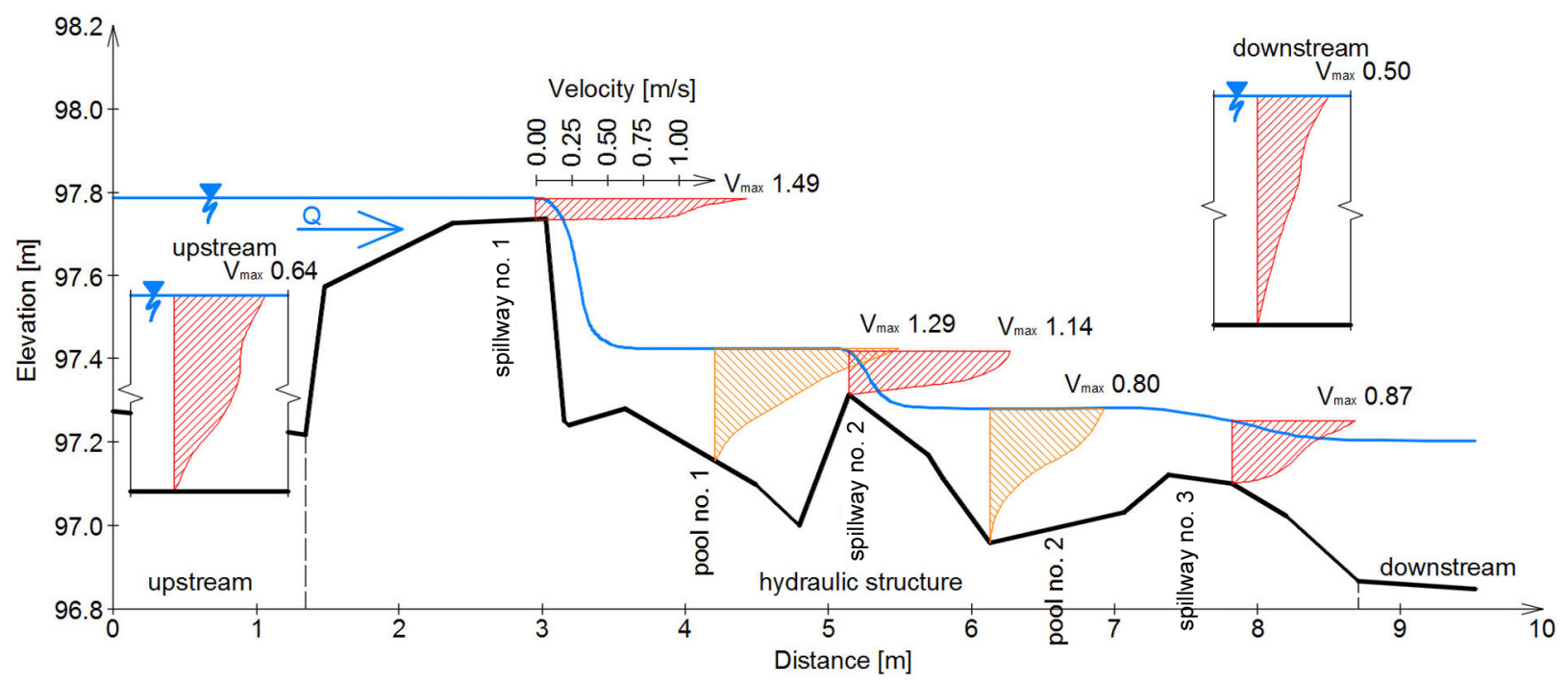

Fig. 5. Profile no. 3

Therefore, although the water drop was as high as $h=0.35 \mathrm{~m}$, trout should be able to swim through this spillway, which is supported by the following:

1. The filling in the pool no. 1 below the spillway no. 1 is large $(h=0.7 \mathrm{~m})$, which according to the equation is enough for trout to give a sufficiently long and high jump (Jelonek and Wierzbicki,
2008). On the other hand, according to Cowx and Welcomme (1998) this suggests that for a spillway of $h=0.35 \mathrm{~m}$ the filling of pool of $h=0.44 \mathrm{~m}$ is sufficient.

2. When water is overflowing through a spillway with a convenient shape, fish does not have to jump for gaining speed that beats the velocity of water 
sliding on across the structure's bed. The maximum value of velocity in the spillway no. 1 was $V_{\max }=1.64 \mathrm{~m} \cdot \mathrm{s}^{-1}$, remaining within the acceptable range. Research literature (Larinier, 2002) indicates that at a velocity of $V=1.64 \mathrm{~m} \cdot \mathrm{s}^{-1}$ trout $L=0.25 \mathrm{~m}$ long is able to swim about $5.5 \mathrm{~m}$ at a water temperature of $10-20^{\circ} \mathrm{C}$. For specimen of length $L=0.35 \mathrm{~m}$ this distance increases significantly above $10 \mathrm{~m}$. Even with taking into account the length of the drop $(0.37 \mathrm{~m})$, and not the drop itself $(0.35 \mathrm{~m})$, it can be unambiguously stated that flow velocity on the spillway will not impede migrating trout.

According to Jelonek and Wierzbicki (2008), possibilities for salmonids migrations are the most recognized. They state that trout are able to overcome obstacles with a height up to $0.8 \mathrm{~m}$. However, with an objection that in order for a fish to make such a long jump, appropriate conditions below the obstacle must be met, such as: sufficient depth of energy dissipation basin or pool as well as its length.

Profile no. 5 was located on the right side of the object, in a place where most of the vegetal debris was deposited, which along with elements detached from the main spillway led to a stepped water table profile. Three limiters were found in this profile, which block the entire structure for all fish species. These are: pools no. 2 and 3 and the main spillway no. 1. Pool no. 3 was characterized by very low filling $(H=0.1 \mathrm{~m})$ and too small dimensions $(L=1.3 \mathrm{~m})$ meaning that these parameters were outside the norms for all species of fish found in the river. Also in pool no. 2 the filling was too low $-H=0.17 \mathrm{~m}$. The third element causing a blockage in fish migration was the main spillway (no. 1) with a $\Delta h=0.36 \mathrm{~m}$ high drop.

The results obtained from the measurements of profile no. 6, which was located on the right side of the facility, indicate that this part with has the highest capacity. It poses no difficulty for trout, grayling, roach and perch. All of these fish species are able to pass through the spillway no. 1, which features the worst hydrodynamic parameters in terms of fish migration. The water drop here is $\Delta h=0.13 \mathrm{~m}$, while flow velocity reached $V_{\max }=1.4 \mathrm{~m} \cdot \mathrm{s}^{-1}$. At spillway no. 2, water flow velocity was similar $\left(V_{\max }=1.36 \mathrm{~m} \cdot \mathrm{s}^{-1}\right)$ to that observed at spillway no. 1, while the water drop was only $\Delta h=0.08 \mathrm{~m}$. The next spillways (no. 3 and 4 ) were much slower than these situated above. Their maximum values were respectively $V_{\text {max }}=0.64 \mathrm{~m} \cdot \mathrm{s}^{-1}$ and $V_{\max }=0.53 \mathrm{~m} \cdot \mathrm{s}^{-1}$ for no. 3 and 4 and the water drop itself was much smaller. At spillway no. 3 it was $\Delta h=0.05 \mathrm{~m}$, while spillway no. 4 was below water

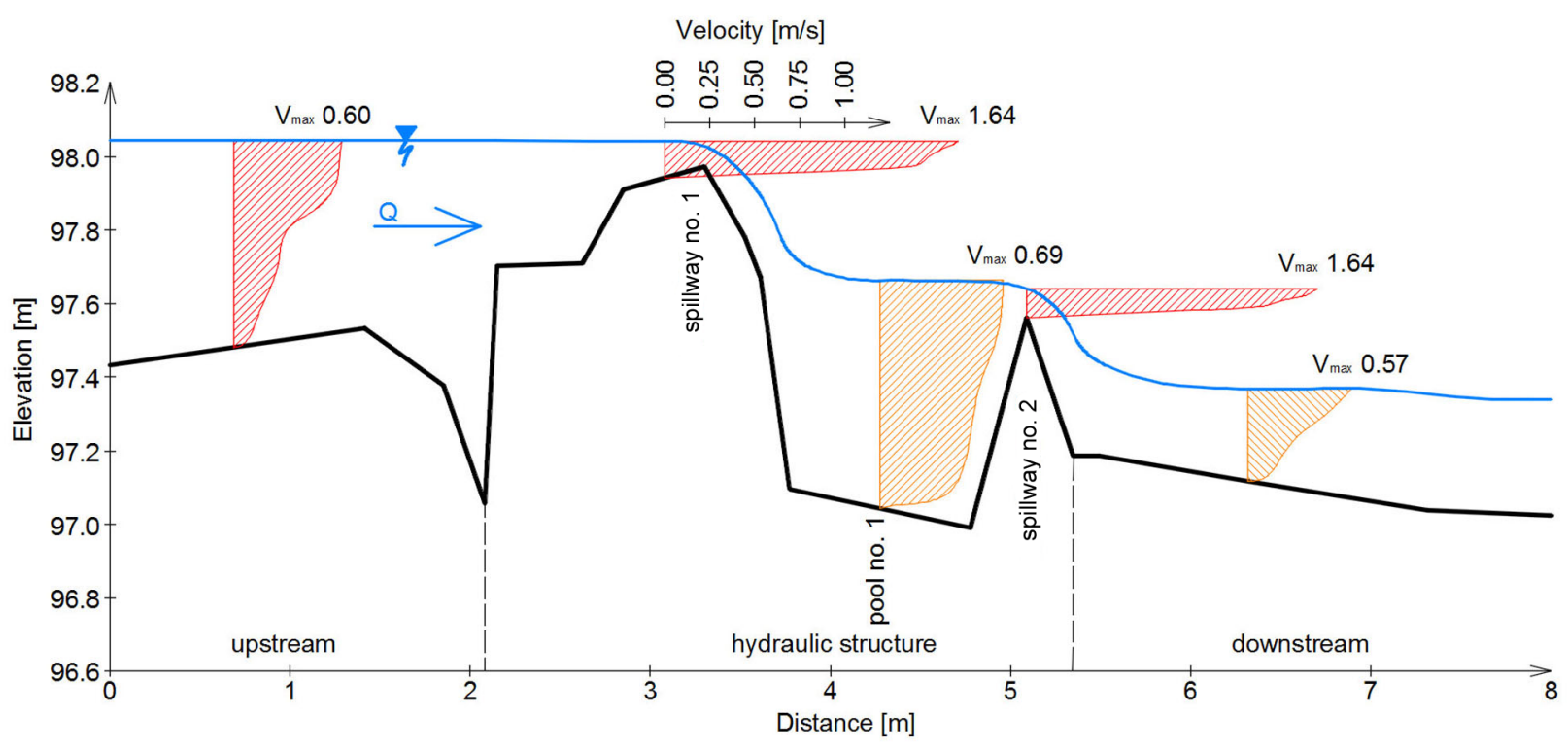

Fig. 6. Profile no. 4 


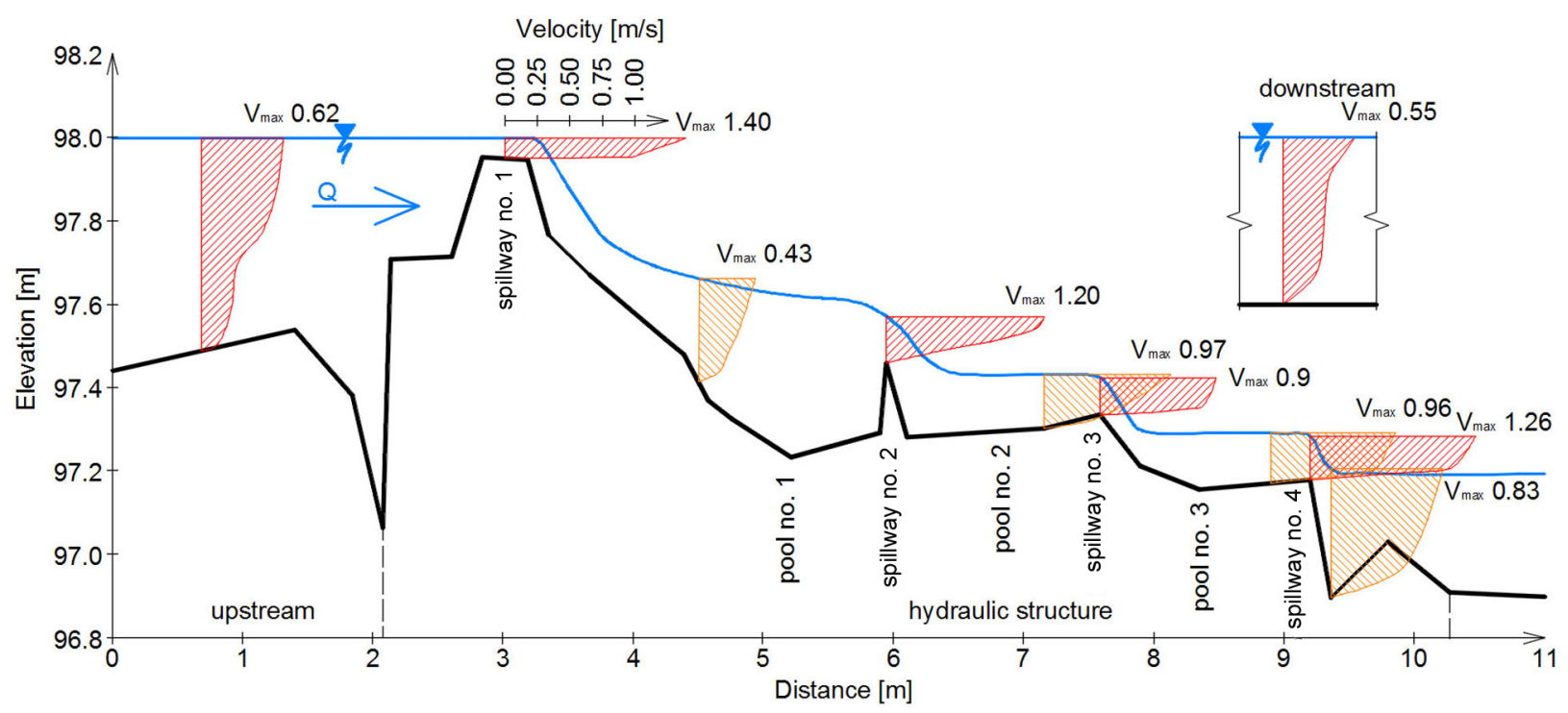

Fig. 7. Profile no. 5

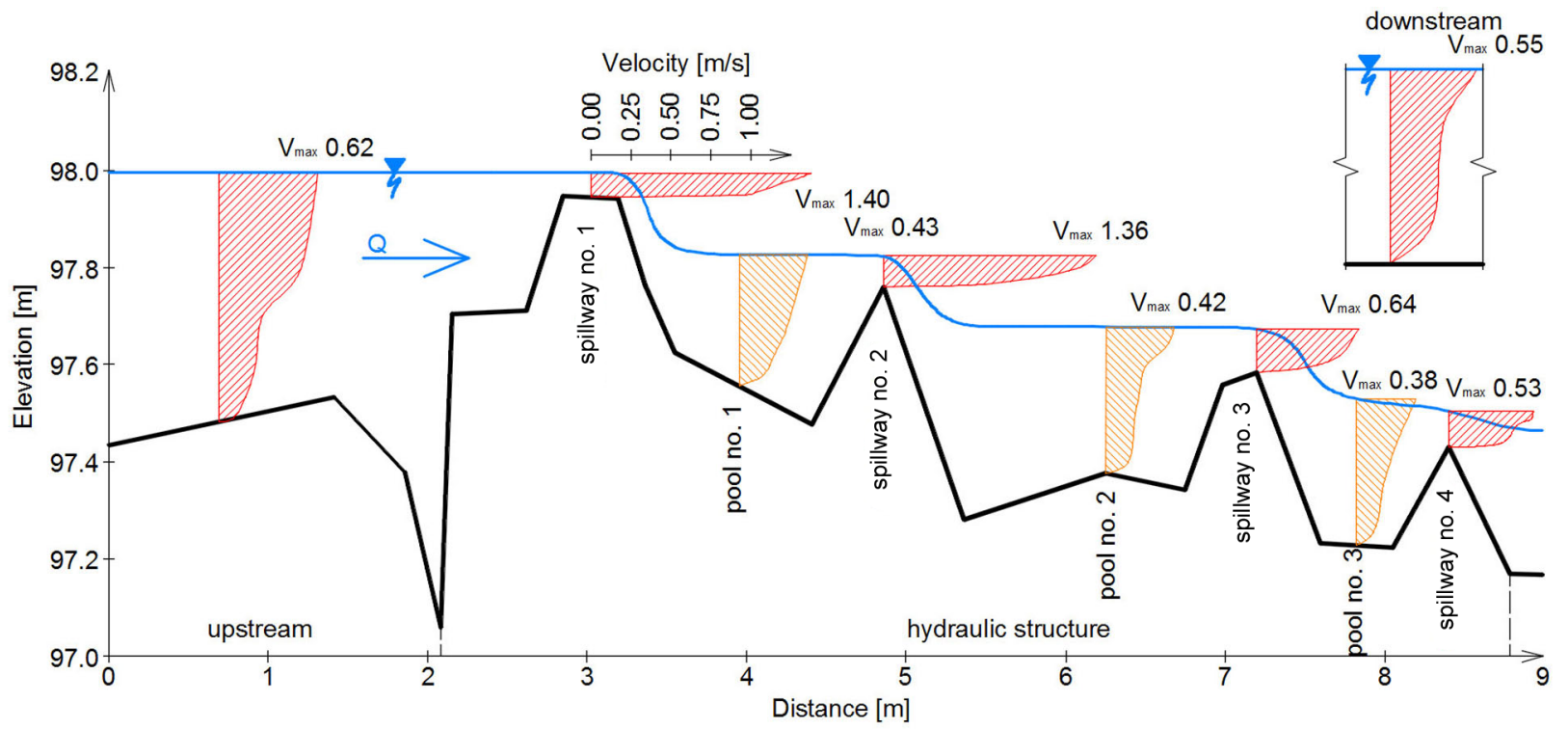

Fig. 8. Profile no. 6

table. On the basis of analysis of hydrodynamic parameters alone it could be proven that fish species with worse jumping and swimming abilities (bream, pike, eel and burbot) could reach pool no. 2. Pool no. 3 could be a significant impediment for mentioned fish, because it was too short $(L=1.5 \mathrm{~m})$ and for some species also too shallow $(H=0.35 \mathrm{~m})$.

\section{SUMMARY}

The object of research was a significantly damaged drop hydraulic structure, which construction elements, usually concrete fragments, were detached from the hydrotechnical structure and deposited near below the facility. These elements affected both the water flow re- 
gime and sedimentation conditions (Judd and Peterson, 1969; Radecki-Pawlik, 2014a, 2014b). These changes were evident by the creation of cascade flow in result of water damming by concrete elements. There were locations with both rapid and shallow current (spillways) as well as slow and deep (pools) (Plesiński et al., 2019). Aggradation of concrete elements in the riverbed below the structure led to subsequent consequences, such as increasing roughness and stopping heavy plant rubble and debris (Plesiński, 2018b; Wyżga et al., 2003; Wyżga, 2007; Radecki-Pawlik, 2014). Debris caused partial choking of the pools created after the aggradation of concrete elements. In turn, the aggradation of heavy vegetal rubble (trunks, roots and branches) caused subsequent water damming, although not as striking as with concrete elements, and velocity loss of flowing water (Curran and Wohl, 2003; Michalec and Tarnawski, 2006; Michalec and Leksander, 2011; Radecki-Pawlik et al., 2011; Kałuża and Radecki-Pawlik, 2014; Linstead, 1999; Gippel, 1995; Manners et al., 2007). In addition, rubble could serve as a hideout from predators for migrating fish. (Wiśniewolski and Gierej, 2011). Harmon et al. (1986) report that in lowland rivers wood rubble is one of the main habitat-forming factors, as it can shape over $50 \%$ of micro-habitats in forest streams. Therefore, roots, trunks and branches can be used to revitalize riverbeds (Pagliara and Kurdistani, 2017).
The facility has not been renovated and modernized for several years. For this reason the detached concrete elements improved migration conditions in the riverbed. However, the structure cannot be said to be completely clear after partial damage. It can be drawn from the research and analyses that it is clear only in some parts and not for all species of fish studied and found in the river (see: Table 2).

Brown trout have the best chances of passing through the drop hydraulic structure. If they enter the right part of the facility (profiles no. 4 and 6) they should be able to reach the upper section of the river. Compared to other analysed species, these fish are characterized by the greatest adaptation to habitats with high flow velocities (spindle-shaped body) and by the ability to jump (Backiel, 1964; Crisp, 2000). Only too high drop can be a limiting parameter for their travel (Schmutz and Mielach, 2013). Water overflowing through a spillway with a sharp edge and falling from a height over $0.20 \mathrm{~m}$ usually is an obstacle impossible to overcome for trout. The situation is slightly different if water flows through a conveniently shaped spillway. Then threshold height may be greater, because fish does not have to jump as it is sufficient to swim along the current (Jelonek and Wierzbicki, 2008). The parameter that could then limit migration is excessive flow velocity, which can cause fish to be pushed back

Table 2. The results of analysis of migratory profiles for fish

\begin{tabular}{|c|c|c|c|c|c|c|}
\hline \multirow{2}{*}{ Species } & \multicolumn{6}{|c|}{ Capacity } \\
\hline & Profile 1 & Profile 2 & Profile 3 & Profile 4 & Profile 5 & Profile 6 \\
\hline Brown trout (Salmo trutta m. fario) & - & - & - & + & - & + \\
\hline Grayling (Thymallus thymallus) & - & - & - & - & - & + \\
\hline Bream (Abramis brama) & - & - & - & - & - & - \\
\hline Roach (Rutilus rutilus) & - & - & - & - & - & + \\
\hline Barbel (Barbus barbus) & - & - & - & - & - & + \\
\hline European Perch (Perca fluviatilis) & - & - & - & - & - & + \\
\hline Northern Pike (Esox lucius) & - & - & - & - & - & - \\
\hline Burbot (Lota lota) & - & - & - & - & - & - \\
\hline
\end{tabular}


into a pool located below a spillway (DVWK, 2002; Gebler, 1991). Velocity limit for brown trout was not exceeded at any measurement point.

Also, grayling, roach, barbel and perch have a chance to swim through the drop hydraulic structure, though it largely depends on where they begin their passage. Only 1 of 6 profiles turned out to be unobstructed for them - it was profile no. 6 , only there concrete elements together with wooden rubble formed a cascade system, where all hydrodynamic parameters, especially water losses and flow velocities, at individual spillways were within the acceptable range (DVWK, 2002; Gebler, 1991; Schmutz and Mielach, 2013). It should be noted that these fish species are characterized by lower swimming capabilities than trout, therefore already two parameters limited the possibility of beating the obstacle for them (DVWK, 2002; Gebler, 1991; Schmutz and Mielach, 2013). In profiles no. 1-5 it was the water drop, while in profile no. 2 and 4 it was water flow velocity, additionally.

Remaining fish species (bream, pike, burbot), also observed in the Dobrzyca River, in accordance with recommendations and standards (DWA, 2014; DVWK, 2002; Gebler, 1991; Schmutz and Mielach, 2013) of permissible values of hydrodynamic parameters for migrating fish, are not capable of crossing the structure. The drop hydraulic structure is a barrier they cannot overpass.

The facility is only partially clear and accessible just for certain species of fish. The research showed that better rates could be expected in the evaluated parameters, so that there were fewer sites impeding the migration of particular fish species. Certainly, the current situation for migrating fish is better than immediately after the drop hydraulic structure was built. Back then none of the species was able to overcome the obstacle with a height of $1.5 \mathrm{~m}$. At present, it can be hoped that the facility left alone will continue to be cleared by nature itself as deterioration and detachment of concrete elements proceeds. Often the obstructed area, in all longitudinal profiles, was the main threshold of the structure, which is still too high at most widths. Its further decline, whether due to nature or man activity, would bring great improvement in conditions for migrating fish. Partial lowering of the structure has already happened due to breaking off of the concrete slab at the crown of the spillway - now a fragment of it remains on a small section on the left side. It should be also understood that so far the damage to the structure does not threaten its tasks. If such a threat (e.g. loss of construction stability, loss of bed stability and significant bed erosion or even increased flood risk) was to occur, then precautionary measures should be taken, like modernization of the facility.

It should be noted that the new arrangement is ever-changing. After a flood, heavy wooden rubble and concrete elements can be displaced, modifying the cross-sections and profiles of the longitudinal watercourse. During such a flood, in which fluvial processes become active, one should count on further renaturization of the riverbed and a next phase of improving fish migration conditions, which according to Osterkamp and Hupp (2010) and Wohl and Scott (2016) is most likely.

\section{ACKNOWLEDGMENTS}

This research was financed by the National Science Centre of the Republic of Poland (2017/01/X/578/02008).

\section{REFERENCES}

Allan, J.D., Flecker, S.A. (1993). Biodiversity conservation in running waters. Identifying the major factors that threaten destruction of riverine species and ecosystems. Bioscience, 43, 32-43.

Backiel, T. (1964). Pstrągi. Warszawa: Państwowe Wydawnictwo Rolnicze i Leśne.

Bartnik, W., Epler, P., Jelonek, M., Klaczak, A., Książek, L., Mikołajczyk, T., Nowak, M., Popek, W., Sławińska, A., Sobieszczyk, P., Szczerbik, P., Wyrębek, M. (2011). Gospodarka rybacka w aspekcie udrażniania cieków dorzecza Małej i Górnej Wisły. Infrastruktura i Ekologia Terenów Wiejskich, 13.

Bojarski, A., Jeleński, J., Jelonek, M., Litewka, T., Wyżga, B., Zalewski, J. (2005). Zasady dobrej prektyki w utrzymaniu rzek i potoków górskich. Departament Zasobów Wodnych, Ministerstwo Środowiska, Warszawa, 143.

Bylak, A. (2018). Wpływ niskich barier na ichtiofaunę przykłady z potoków Karpackich. Rocz. Nauk. PZW, 31, 5-19.

Bylak, A., Kukuła, K., Plesiński, K., Radecki-Pawlik, A. (2017). Effect of a baffled chute on stream habitat conditions and biological communities. Ecol. Eng., 106, 263-272. 
Bylak, A., Kukuła, K., Kukuła, E. (2009). Influence of regulation on ichthyofauna and benthos of the Różanka stream. Ecohydrol. Hydrobiol., 9, 211-223.

Cowx, I. G., Welcomme, R. L. (1998). Rehabilitation of Rivers for Fish. Oxford: Fishing News Books, Blackwell Science.

Crisp, T. D. (2000). Trout and salmon: ecology, conservation and rehabilitation. London: Wiley-Blackwell.

Curran, J.H., Wohl, E.E. (2003). Large woody debris and flow resistance in step-pool channels, Cascade Range, Washington. Geomorphology, 51, 141-157.

Dąbkowski, L., Skibiński, J., Żbikowski, A. (1982). Hydrauliczne podstawy projektów wodnomelioracyjnych. Warszawa: Państwowe Wydawnictwo Rolnicze i Leśne.

Durkowski, T. (2017). Zlewnia rzeki Iny. Budowa niebieskiego korytarza ekologicznego wzdłuż doliny rzeki Iny i jej dopływów. Szczecin: Zachodniopomorski Zarząd Melioracji i Urządzeń Wodnych w Szczecinie.

Dyrektywa 2000/60/WE Parlamentu Europejskiego i Rady z dnia 23 października 2000 r. ustanawiająca ramy wspólnotowego działania w dziedzinie polityki wodnej.

DVWK. (2002). Fish passes. Design, dimensions and monitoring. Rome: DVWK, FAO.

DWA (2014). DWA-Merkblatt M 509. Fischaufstiegsanlagen und fischpassierbare Bauwerke.

Gebler, R.J. (1991). Naturgemäße Bauweisen von Sohlenbauwerken und Fischaufstiegen zur Vernetzung der Fließgewässer. Diss. Univ. Karlsruhe, Mitteilungen des Institutes für Wasserbau und Kulturtechnik, Nr. 181

Gippel, Ch. J. (1995). Environmental hydraulics of large woody debris in streams and rivers. Journal of Environmental Engineering, 121, 388-395.

Jelonek, M., Wierzbicki, M. (2008). Prezentacja technicznych możliwości przywrócenia wędrówek ryb w rzekach na podstawie wybranych przykładów inwestycji zrealizowanych we Francji i Niemczech oraz USA. Kraków - Poznań: Ministerstwo Rolnictwa i Rozwoju Wsi.

Jędryka, E. (2009). Zabudowa hydrotechniczna rzek w aspekcie potrzeb migracyjnych ryb. Woda - Środowiska - Obszary Wiejskie, 9, 3(27), 39-56.

Judd, H.E., Peterson, D.F. (1969). Hydraulics of Large Bed Element Channels, Raport, Utah Water Research Laboratory, College of Engineering, Utah State University.

Harmon, M.E., Franklin, J.F., Swanson, F.J., Sollins, P., Gregory, S.V., Lattin, J.D., Anderson, N.H., Cline, S.P., Aumen, N.G., Sedell, J.R., Lienkaemper, G.W., Cromack, K., Cummins, K.W. (1986). Ecology of coarse woody debris in temperate ecosystems. Advances in Ecological Research, 15, 133-302.
Kałuża, T., Hammerling, M. (2015). Problemy projektowania i eksploatacji przepławek dla ryb. Poznań: Bogucki.

Kałuża, T., Radecki-Pawlik, A. (2014). Wpływ rumoszu drzewnego na hydrodynamikę koryt rzecznych. Acta Scientiarum Polonorum, Formatio Circumiectus, 13(1), 67-80.

Kałuża, T., Radecki-Pawlik, A., Szoszkiewicz, K., Plesiński, K., Radecki-Pawlik, B., Laks, I. (2018). Plant basket hydraulic structures (PBHS) as a new river restoration measure. Science of the Total Environment, 627, 245-255.

Kałuża, T., Szoszkiewicz, K., Radecki-Pawlik, A., Walczak, N., Plesiński, K. (2016). Impact of river restoration on hydromorphological processes: The river Flinta as a case study. (In:) Rowiński P., Marion P. (eds.) GeoPlanet: Earth and Planetary Sciences, Hydrodynamic and Mass Transport at Freshwater Aquatic Interfaces, 183-196, Springer.

Kondracki, J. (2000). Geografia regionalna Polski.Warszawa: PWN.

Kukuła, K. (2003). Structural changes in the ichthyofauna of the Carpathian tributaries of the River Vistula caused by anthropogenic factors. Suppl Acta Hydrobiol., 4, 1-63.

Kukuła, K., Bylak, A. (2011). Wpływ czynników antropogenicznych na faunę karpackich dopływów Wisły. Rocz. Bieszcz., 11, 207-222.

Kukuła, K., Kukuła, E., Kulesza, K. (2008). Niska zabudowa poprzeczna jako czynnik zagrażający ichtiofaunie. [In:] Mokwa, M., Wiśniewolski, W. (red.) Ochrona ichtiofauny w rzekach z zabudową hydrotechniczną. Wrocław: Dolnośląskie Wydawnictwo Edukacyjne, 60-65.

Larinier, M. (2002). Czynniki biologiczne, które należy uwzględniać przy projektowaniu urządzeń migracji ryb w górę rzeki. Bulletin Francais de la Peche et de la Pisciculture. Bulletin Francais de la Peche et de la Protection des Milieu Aquatiques, 364, 3.

Linstead, C. (1999). The effect of large woody debris accumulation on the river hydraulics and implication for physical habitat. Hydroecology: Linking Hydrology and Aquatic Ecology, Proceedings of Workshop in Birmingham, IAHS Publication 266, 91-99.

Lubieniecki, B. (2002). Przepławki i drożność rzek, Olsztyn: Wydawnictwo Instytutu Rybactwa Śródlądowego.

Manners, R.B., Doyle, W.W., Small, M.J. (2007). Structure and hydraulics of natural woody debris jams. Water Resources Research, 43, 1-17.

Michalec, B., Leksander, B. (2011). Określenie bezwymiarowego współczynnika oporów i współczynnika szorstkości w przekroju zatoru z grubego rumoszu drzewnego. Infrastruktura i Ekologia Terenów Wiejskich, 10, 63-70. 
Michalec, B., Tarnawski, M. (2006). Wpływ zatorów z rumoszu drzewnego na przepustowość koryta rzeki Czarna Staszowska. Zeszyty Naukowe Akademii Rolniczej w Krakowie, Inżynieria Środowiska, 433(27), $203-211$

Osterkamp, W.R., Hupp, C.R. (2010). Fluvial processes and vegetation - Glimpses of the past, the present, and perhaps the future. Geomorphology, 116, 274-285.

Pagliara, S., Kurdistani, S.M. (2017). Flume experiments on scour downstream of wood stream restoration structures. Geomorphology, 279, 141-149.

Penczak, T., Lubón-Cerviá, J., O’Hara, K., Jakubowski, H. (1986). Production and food consumption by fish populations in the Piława and Dobrzyca rivers, North Poland. Polskie Archiwum Hydrobiologii, 33, 3/4, 345-372.

Plesiński, K. (2018a). Variability of the river bed system and morphology in the region of the block ramp impact (the case of the Porębianka river). Acta Scientiarum Polonorum, Formatio Circumiectus, 17(1), 79-93.

Plesiński, K. (2018b). Wpływ rumoszu drzewnego na granulometrię osadów korytowych. Przegląd Naukowy Inżynieria i Kształtowanie Środowiska, 27(1), 42-56.

Plesiński, K., Gibbins, C. N., Radecki-Pawlik, A. (2019). Effects of interlocked carpet ramps on upstream movement of brown trout Salmo trutta in an upland stream. Journal of Ecohydraulics, Taylor\&Francis, on-line, DOI: $10.1080 / 24705357.2019 .1581102$

Prus, P., Popek, Z., Pawlaczyk, P. (2018). Dobre praktyki utrzymania rzek. Warszawa.

Radecki-Pawlik, A. (2014a). Hydromorfologia rzek i potoków górskich. Działy wybrane. Kraków: Wydawnictwo Uniwersytetu Rolniczego w Krakowie.

Radecki-Pawlik, A. (2014b). Problemy utrzymania koryt rzecznych bliskich naturze. (In:) Kałuża T., Strzeliński P. (ed.) Problemy gospodarowania wodą na terenach leśnych, zurbanizowanych i niezurbanizowanych. Poznan: Bogucki, Wydawnictwo Naukowe, 91-109.

Radecki-Pawlik, A., Plesiński, K., Pałyga, M. (2015). W sprawie przepławek dla ryb - przykłady z praktyki. (In:) Kałuża T., Hammerling M. (red.) Problemy projektowania i eksploatacji przepławek dla ryb. Poznan: Bogucki Wydawnictwo Naukowe, 13-29.

Radecki-Pawlik, A., Plesiński, K., Radecki-Pawlik, B. (2017). Rozkład prędkości oraz naprężeń stycznych w komorach przepławki typu wielkokomorowego. Acta Scientiarum Polonorum, Formatio Circumiectus, 2017, 16(1), 149-159.

Radecki-Pawlik, A., Wieczorek, M., Plesiński, K. (2011). Zróżnicowanie parametrów hydrodynamicznych cieku w miejscu zdeponowania grubego rumoszu drzewnego.
Acta Scientiarum Polonorum, Formatio Circumiectus, 10(2), 35-46.

Schmutz, S., Mielach, C. (2013). Measures for ensuring fish migration at transversal structures. Technical paper. ICPDR - International Commission for the Protection of the Danube River.

Sakowicz, S., Żarnecki, S. (1954). Przepławki komorowe. Biologiczno-rybackie zasady projektowania. Roczniki Nauk Rolniczych, Warszawa: PWRiL, 69, D.

Seliger, C., Zeiringer, B. (2018). River connectivity, habitat fragmentation and related restoration measures. (W:) Schmutz S., Sendzimir J. Riverine Ecosystem Management, Aquatic Ecology, series 8, 171-186.

Szałkiewicz, E., Dysarz, T., Kałuża, T., Malinger, A., Radecki-Pawlik, A. (2019). Analysis of in-stream restoration structures impact on hydraulic condition and sedimentation in the Flinta River, Poland, Carpathian Journal of Earth and Environmental Sciences, 14, 2, 275-286.

Vannote, R.L., Minshall, G.W., Cummins, K.W., Sedel, J.R., Cushing, C.E. (1980). River continuum concept. Canadian Journal of Fisheries and Aquatic Sciences, 37, 1, 130-137.

Wiśniewolski, W., Augustyn, L., Bartel, R., Depowski, R., Dębowski, P., Klich, M., Kolman, R., Witkowski, A. (2004). Restytucja ryb wędrownych a drożność polskich rzek. WWF Polska.

Wiśniewolski, W., Gierej, A. (2011). Regulacja rzek a ichtiofauna - skutki i środki zaradcze. Roczniki Naukowe PZW, Użytkownik Rybacki - Kondycja polskiego rybactwa śródlądowego, Konferencja, Spała, 109-122.

Witkowska, M., Płowens, T., Humiczewski, M. (2013a). Budowa niebieskiego korytarza ekologicznego wzdłuż doliny rzeki Regi i jej dopływów. Gospodarka Wodna, 10, 403-405.

Witkowska, M., Płowens, T., Humiczewski, M. (2013b). Budowa niebieskiego korytarza ekologicznego wzdłuż doliny rzeki Regi i jej dopływów, część II. Gospodarka Wodna, 11, 444-445.

Wohl, E., Scott, D.N. (2016). Wood and sediment storage and dynamics in river corridors. Earth Surface and Processes Landforms, 42, 1, 5-23.

Wyżga, B. (2007). Gruby rumosz drzewny: Depozycja w rzece górskiej, postrzeganie i wykorzystanie do rewitalizacji cieków górskich. IOP PAN Kraków, monografia.

Wyżga, B., Zawiejska, J., Kaczka, R. (2003). Gruby rumosz drzewny w ciekach górskich - formy występowania, warunki depozycji i znaczenie środowiskowe. Folia Geographica, Geographica-Physica, 33-34, 117-138.

Żelazo, J., Popek, Z. (2014). Podstawy renaturyzacji rzek. Warszawa: Wydawnictwo SGGW. 


\section{PROCES NATURALNEJ RENATURYZACJI CIEKU NA PRZYKŁADZIE USZKODZONEGO STOPNIA WOD- NEGO: RZEKA DOBRZYCA, POLSKA PÓŁNOCNO-ZACHODNIA}

\section{ABSTRAKT}

\section{Cel pracy}

W artykule przedstawiono ocenę drożności stopnia wodnego znajdującego się na rzece Dobrzycy, w miejscowości Rudki, w gminie Wałcz, w północno-zachodniej Polsce. Stopień został częściowo zniszczony, a koryto rzeczne w tym rejonie uległo powolnej renaturyzacji. W wyniku uszkodzeń obiektu przez procesy towarzyszące siłom natury (tu: głównie wezbraniom, lecz także erozji dna), elementy wyrwane z budowli zostały zdeponowane w niecce wypadowej i w korycie poniżej obiektu, zatrzymując wleczone rumowisko i rumosz roślinny. Procesy te sprawiły utworzenie się struktury kaskadowej powodującą zmianę reżimu przepływu wody przez budowlę hydrotechniczną, która nie była planowana ani projektowana. Zgodnie z obecnymi wymaganiami środowiskowymi, budowa stopnia wodnego o spadowej ścianie bez zastosowania budowli towarzyszących w postaci przepławek lub kanałów obiegowych nie jest możliwa.

\section{Materiat i metody}

Na skutek zniszczenia częściowego obiektu, został zmieniony reżim przepływu wody przez stopień, na tyle, że możliwe jest pokonanie odcinka rzeki, na którym zbudowany był stopień przez ryby różnych gatunków, bez konieczności budowy urządzeń dodatkowych. W wyniku pomiarów terenowych wyznaczono 6 potencjalnych dróg migracji ryb przez rejon uszkodzonego stopnia. Następnie oceniono każdą z dróg pod kątem możliwości przepłynięcia ryb z gatunków występujących w rzece.

\section{Wyniki i wnioski}

Analiza wykazała, że zniszczenia częściowo udrożniły budowlę stwarzając dogodne warunki do migracji niektórych gatunków ryb. Można wnioskować, że fragmenty oderwane z budowli i zdeponowane w korycie poniżej obiektu należy pozostawić. Elementów nie należy usuwać z niecki wypadowej i koryta, gdyż polepszają warunki środowiskowe dla organizmów wodnych. Omawiany przypadek można więc potraktować jako naturalną renaturyzację rzeki i częściowego udrożnienia budowli wodnej przez procesy fluwialne zachodzące w korycie cieku.

Słowa kluczowe: stopień wodny, renaturyzacja, migracja ryb, rzeka Dobrzyca 